\title{
Inicial experience using valved porcine xenografts in the rigth ventricule outlet for congenital anomalies
}

\author{
Experiência inicial da utilização do xenoenxerto valvado porcino na via de saída do ventrículo direito \\ em cardiopatias congênitas
}

\author{
Gláucio FURLANETTO, Beatriz H. S. FURLANETTO, David T. CHEUNG, Ivan S. J. CASAGRANDE
}

RBCCV 44205-858

In spite of the advances achieved in congenital anomaly surgery, an adequate substitute for the pulmonary trunk and valve has not been found. Many valvar conducts are attained using tissues fixed in glutaraldehyde, which has a cytotoxic action resulting in an immunogenic reaction limiting good long-term results due to inflammation, thrombosis and calcification [1]. Porcine valvar xenografts fixed using the glutaraldehyde technique have been widely used worldwide and present with variable middle- and logterm results with between $4.2 \%$ and $35 \%$ of patients being submitted to reoperations due to xenograft valve dysfunction [2]. The utilization of cryopreserved aortic and pulmonary homografts for the reconstruction of the right circulation is common. Homograft dysfunction can also occur with this valved conduit, with the necessary of reoperation for its replacement. Immunologic mechanisms and not just a simple lack of growth are involved in graft failure in these cases [3]. Bioprostheses obtained by tissue engineering utilizing biodegradable frameworks present limitations because of their rigidity and high porosity [4]. Recently, bovine jugular veins with the native valve have been used with good immediate and middle-term results [5].
This graft presents with a compatible texture when anastomosed to pulmonary arteries in newborn babies. Glutaraldehyde is utilized in its preparation and thus all the consequences of this, as previously mentioned, will be seen in the patient's evolution. Isolated decellularization of homografts is still in the initial phase of study, but this may be another option to minimize degeneration of this graft [6].

Based on experimental studies, the utilization of L-Hydro valved porcine xenografts (PVX) in the pulmonary position of newborn lambs, where growth of this graft with preservation of the valve function was demonstrated, clinical studies in children with congenital anomalies and alterations of the right ventricle outflow tract were begun.

The L-Hydro method of preservation initially consists of the use of $50 \%$ alcohol to preserve and transport the grafts. Following this, the grafts are treated in a solution containing sodium chloride, polyethyleneglycol, hydrogen peroxide, sodium phosphate and indomethacin at a temperature of between $4^{\circ} \mathrm{C}$ and $8^{\circ} \mathrm{C}$. At the end of this treatment, the sodium chloride, polyethyleneglycol, hydrogen peroxide and sodium phosphate are removed and the final product is preserved in 50\% alcohol (Figure 1).

\footnotetext{
Work carried out in the Pediatric Heart Surgery Department of the Real e Benemérita Associação Portuguesa de Beneficência in São Paulo - Rua Maestro Cardim, 769 Paraíso. São Paulo-SP

Work presented at the 32nd Congress of the Brazilian Society of Cardiovascular Surgery, Espírito Santo in April 2005

Correspondence address:

Rua Maestro Cardim 560, Sala 73, São Paulo, SP, Brazil, CEP 01223000 .

Fax/Tel: (11) 32847686.

E-mail: gfurlanetto@terra.com.br
} 


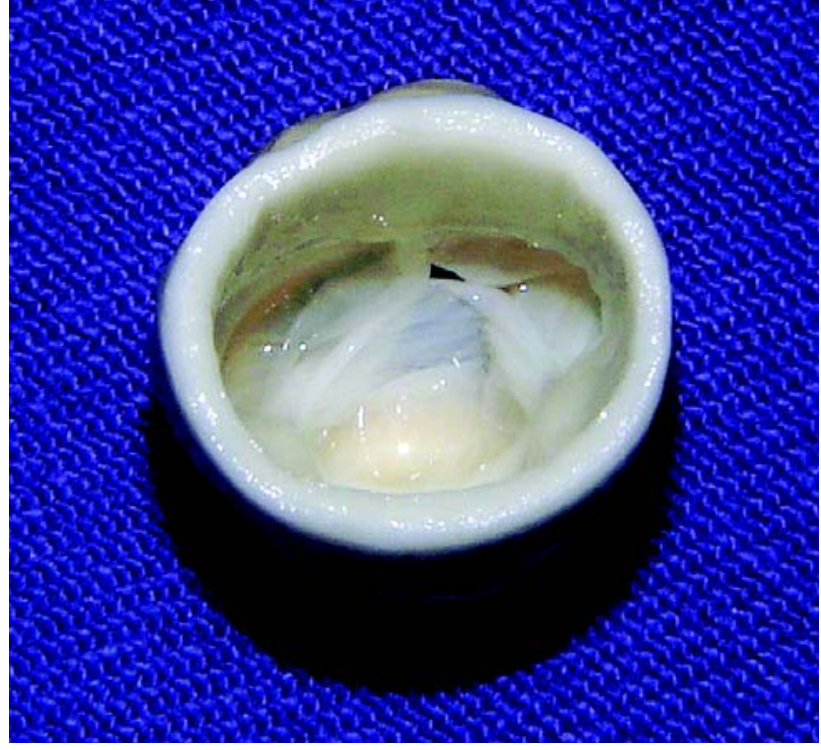

Fig. 1 -Aspect of the porcine valve xenograft treated with $L$-Hydro prior to implantation

L-Hydro valved porcine xenografts were used in three children: Patient 1 -A one-month-old child weighting $3.5 \mathrm{~kg}$ with tetralogy of Fallot was submitted to the closing of a interventricular communication (IVC) and the placement of a 11-mm valved porcine xenograft in the pulmonary position (Figure 2). Patient 2 -A ten-month-old child weighting $7 \mathrm{~kg}$ with tetralogy of Fallot was submitted to interventricular communication repair with the placement of a $15-\mathrm{mm}$ valved porcine xenograft in the pulmonary position. Patient 3 - A four-month-old infant weighting $3.3 \mathrm{~kg}$ with pulmonary atresia and type-A interventricular communication was submitted to interventricular communication repair with the placement of a 13-mm valved porcine xenograft in the pulmonary position.

The evolutions of the three children in the intensive care unit and on the ward were uneventful and they were discharged from hospital in good clinical conditions. Colored Doppler examinations performed in the immediate postoperative period showed excellent results, with good functioning of the valve graft.

Based on this initial group, a study protocol with comparative measurements of size and functionality of the valved porcine xenograft was established.

The clinical evolution of the patients was satisfactory and providing basis for a multicentric study aiming at evaluating this new type of valved graft, that has a potential for growth. The good preliminary immediate results must be reproduced using a larger number of patients and followed up over the middle- and long-terms to reach a definitive conclusion on the possible of using this graft.

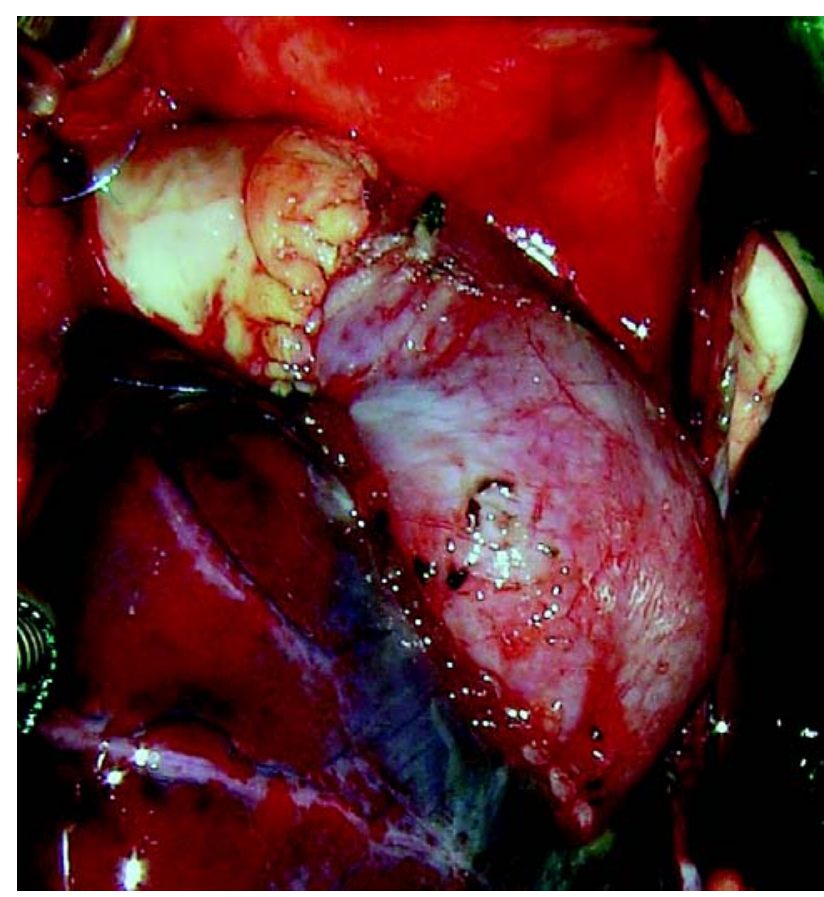

Fig. 2 - L-Hydro porcine xenograft implanted in the right ventricle outflow tract and enlarged using fresh autologous pericardium

\section{REFERENCES}

1. Shen M, Carpentier S, Berrebi AT, Chen L, Martineti B, Carpentier A. Protein adsorption of calcifield and noncalcified valvular bioprostheses after human implantation. Ann. Thorac. Surg 2001; 71: 406-7. Supplement.

2. Champsaur G, Robin J, Curtil A, Tronc F, Vedrinne C, Sassolas F et al. Long-term clinical and hemodynamic evaluation of porcine valved conduits implanted from the right ventricle to the pulmonary artery. J Thorac Cardiovasc Surg 1998; 116 (5): 793-804.

3. Hawkins JA, Breinholt JP, Lambert LM, Fuller TC, Profaizer T, McGough EC, et al. Class I and class II anti-HLA antibodies after implantation of cryopreserved allograft material in pediatric patients. J Thorac Cardiovasc Surg 2000; 119 (2): 324-30.

4. Shinoka T, Shum-tim D, Ma PX, Tanel RE, Isogai N, Langer R, et al. Creation of viable pulmonary artery autografts through tissue engineering. J. Thorac. Cardiovasc. Surg 1998;115:536-46, 1998.

5. Corno AF, Qanadli SD, Sekarski N, Artemisia S, Hurni M, Tozzi $\mathrm{P}$, et al. Bovine valved xenograft in pulmonary position: mediumterm follow-up with excellent hemodynamics and freedom from calcification. Ann Thorac Surg 2004; 78 (4): 1382-8.

6. Costa FDA, Dohmen P, Lopes SV, Pohl F, Vilani R, Vieira E, et al. Estudo experimental com homoenxertos valvares descelularizados: a prótese do futuro. Rev. Bras. Cir. Cardiovasc 2004; 19 (1): 74-82. 